\title{
FILM U DJEČJOJ RADIONICI na primjeru Društva Naša djeca Motovun
}

\author{
Sandra Vlahov, diplomantica \\ Odjel za odgojne i obrazovne znanosti, \\ Sveučilište Jurja Dobrile u Puli (Hrvatska) \\ e-mail: $\underline{\text { sandra.vlahov2@ @u.t-com.hr }}$ \\ Mr. sc. Ivan Grgurević \\ Odjel za odgojne i obrazovne znanosti, \\ Sveučilište Jurja Dobrile u Puli (Hrvatska) \\ e-mail: grgurevic.ivan@gmail.com
}

\section{Sažetak}

U radu polazimo od činjenice da je suvremeno društvo preplavljeno medijima (tiskovine, fotografija, film, televizija, video, internet, računalne igre). Djeca rastu zajedno s njima bez većeg utjecaja roditelja, učitelja ili drugih odraslih. Mediji bogate znanje i doživljaj djeteta $\mathrm{i}$ ne treba se protiv njihova negativnoga utjecaja boriti zabranama, osudama ili cenzurom, nego učenjem o medijima i njihovu karakteru. Krajnji je cilj „,razumijevanje medija" i kreativno korištenje njegovih mogućnosti.

Tema je našega rada filmski medij u dječjoj radionici. U radu smo nastojali ukazati na utjecaj filma (ekrana) na odgoj, o potrebi uvođenja nastave o filmu u školu, a opisali jedan mogući oblik filmske izvannastavne aktivnosti djece. Na primjeru Filmske radionice Društva Naša djeca Motovun nastojali smo pokazati sve radnje i postupke „od ideje do premijere" (uvodni susret, razgovor o izboru teme i ideje za film, izrada sinopsisa i scenarija, upoznavanje s filmskom tehnologijom, snimanje, montaža, ozvučenje, premijera).

Zaključili smo kako je najefikasnija metoda da djeca nauče i shvate „karakteristike i učinke" medija (McLuhan) u igri znanja i kreativnosti pri snimanju filma u dječjoj radionici. Kao što je literarni sastavak stupanj nakon što se nauči čitati i pisati, tako je filmski i video uradak više od osnovnoga znanja o izražajnim sredstvima medija, a djeca će vrlo brzo shvatiti da je film specifičan medij u kojem, pored ostaloga, vlastitu kreativnost treba uskladiti s drugačijim kreativnostima. Filmska radionica trebala bi biti temeljnim oblikom dječjega bavljenja filmom i pretpostavka kinoklubovima. Ako filmsko djelo izostane, ostat će nešto od vještine audiovizualne komunikacije i kritičnosti u odnosu na medij ili barem kreacija u igri, što je, za razliku od kinokluba, za filmsku radionicu sasvim dostatno.

Ključne riječi: medij, film, dječja radionica, Motovun 


\section{Uvod}

Širenjem televizije i videa prigovori upućeni televiziji, zbog jednakih ili sličnih izražajnih sredstava, sve se više usmjeravaju prema filmu. Zbog velike srodnosti medija odgojne negativnosti televizije ujedno su i negativnosti filma. Tako se ističe da film potiče nasilnost, grubost, okrutnost i otupljuje osjetljivost mladih na zlo i nasilje. Film potiče na kriminal, podučava o kriminalu, privlači i ohrabruje buduće kriminalce. Film, udružen s televizijom, ljude sve više razdružuje, otuđuje čovjeka od čovjeka. Videorekorder i računalo stanje otuđenosti pojačavaju i prijete daljnjim bijegom u osamu i zatvorenost. Prividnom životnom uvjerljivošću film i televizija pasiviziraju duh i umrtvljuju um, pa dijete dobiva, bez umnog i tjelesnog truda, sve što poželi. Film i televizija zapljuskuju mladu publiku jezičnim supstandardom, rječnikom lascivnosti i psovkom. Zbog zabave na ekranu mlade generacije gube interes za sve ozbiljno, nezabavno, naporno, teže ostvarivo. Televizija je produžetak vlasti koja pruža goleme mogućnosti upravljanja ljudima radi komercijalnih i političkih ciljeva. Televizija je snažno oruđe u oblikovanju mišljenja i svjetonazora ljudi i djece.

U našem odgojno - obrazovnom sustavu medijska kultura pripojena je nastavi hrvatskog jezika i književnosti. Naši stručnjaci uviđaju probleme i slaba znanja kod djece o medijima i medijskoj kulturi pa uz višegodišnje napore i sve veće potrebe za osamostaljivanjem ovog područja uspijevaju dobiti sve dozvole za uvođenje predmeta Medijska kultura kao potpuno izdvojenog i samostalnog što se očekuje u sustavu za tri godine (prikaz prof. K. Mikića na 12. školi medijske kulture 2010). Pojavi li se kao obvezni ili izborni predmet u školama sigurno će plijeniti pažnju djece i mladih.

Zbog sveprisutnosti i atraktivnosti medija, pozornost djece i mladih plijene i izvannastavne filmske i video aktivnosti. Česti su oblici školske sekcije, družine, kinoklubovi, a manje filmske radionice, iako bi se u njima morao kriti neposredni kreativni potencijal. Tema je našega rada dječja filmska radionica kao oblik izvanškolske aktivnosti djece općenito i radionica u Društvu Naša djeca Motovun kao pojedinačan primjer.

\section{Film u dječjoj radionici: Filmske izvannastavne aktivnosti učenika}

Škola je (uz filmske i video družine) prvo mjesto gdje bi mladi čovjek trebao ponirati u bit fotografije, filma i videa. Najznačajniji profesori, Težak i Peterlić, bili su toga svjesni i zaslužni su za uvođenje filmske umjetnosti u škole. Kako je malo predviđenih nastavnih sati za rad na filmu i medijskoj kulturi važno je pobliže upoznati i izvanučioničku nastavu i izvannastavne aktivnosti vezane uz film.

„Slobodne aktivnosti obuhvaćaju skup oblika odgojno-obrazovnog djelovanja kojim se u osnovnu školu i njen sistem odgoja unose elementi dječjeg društveno korisnog i proizvodnog rada, razvijaju postojeći i stvaraju novi interesi, proširuje $i$ produbljuje znanje učenika, razvija kultura rada, smisao za usklađivanje osobnih i društvenih interesa i utječe na zbližavanje učenika i nastavnika. One proširuju i obogaćuju djelatnost osnovne škole i pozitivno utječu na svestraniji i slobodniji odgoj učenika. Svojim sadržajem i oblicima slobodne aktivnosti znatno pridonose integraciji 
škole i društva. Odgojno-obrazovno djelovanje škole se širi i postaje značajan činilac u zajedničkom djelovanju s raznim izvanškolskim faktorima." (Težak, 1979,7)

U školskoj praksi razvilo se više različitih varijanata učeničkih izvannastavnih aktivnosti sa sadržajima iz područja filma i televizije: filmske družine ili sekcije debatnog tipa, kinoamaterski klubovi, RTV-sekcije ili družine, školski televizijski klubovi, RTV-novinarske sekcije, literarno-filmske družine i slično.

\section{Školski kinoklubovi i kinoamaterske sekcije}

Kinoklubovi usmjereni su na filmsko stvaralaštvo. Oni su zahtjevni u smislu vođenja i opreme, no i plodonosniji od sekcija debatnog tipa. U njima se filmska kultura stječe vlastitim stvaralačkim pokušajima izražavanja i dublja je od one koja se zasniva samo na promatranju tuđih filmskih ostvarenja. Pored raznolikog znanja (tehničkog, literarnog, scenskog, filmološkog) djeca stječu i svestraniji odgoj: estetski, etički, radni, intelektualni i drugi. opasnosti:

Kako bi se odgojne i obrazovne prednosti iskoristile valja imati na umu i moguće

1. prikrivanje nastavnikovih neiživljenih filmskih ambicija. Nastavnik je pokretač i glavni voditelj svih akcija, a učenici su samo pomoćnici - tehničko i glumačko osoblje

2. oponašanje profesionalne kinematografije $u$ negativnom smislu (samoreklamiranje, kult zvijezda)

3. nasilno pedegogiziranje kada se odgojna uloga filma prenaglašava u težnji da svaki film nosi jasnu odgojnu poruku

4. niski dometi filmskog zanata kada se prednost daje priči i sadržaju, a režija, montaža i gluma ne dostižu višu razinu

5. preopterećivanje učenika, jer se ne vodi računa o slobodnom vremenu pa se dijete preopterećuje vremenski, fizički, intelektualno: nije dobro planirati akcije koje nadilaze snage članova, npr. dugometražne filmove.

Kinoklubovi su najčešće vezani uz pojedine školske i odgojno-obrazovne ustanove, ali se javljaju i kao samostalna udruženja mladih. U Hrvatskoj kao najuspješniji nositelji i promicatelji školskog filmskog stvaralaštva afirmirali su se kinoklubovi Slavica iz Pitomače, Iskra iz Jasenovca, Videodružina COOO Dubrava iz Zagreba, Škola animiranog filma Čakovec (ŠAF)...

Metode rada u kinovideo klubu su:

a) debatna metoda kojom se upoznaju osnovne kategorije filmskog izraza

b) praktičan rad u kojem se ovladava filmskom tehnikom kao preduvjetom za realizaciju vlastitih filmova

c) stvaralački rad, koji je cilj cjelokupne aktivnosti, a rezultira ostvarivanjem filmova. (Težak, 2002, 421)

„Učeničko stvaralaštvo se ne potiče radi otkrivanja i odgajanja budućih umjetnika, filmskih radnika i stručnjaka, premda se kao izuzeci mogu pojavljivati i takvi rezultati, niti se očekuju visoki umjetnički dometi učeničkih stvaralačkih pokušaja pa ni 
omasovljenje dječjeg i omladinskog kinoamaterizma, makar ni u tom pravcu ne treba odbijati moguće pozitivne posljedice. Obogatiti djetinjstvo i mladost radošću stvaranja, otkriti učeniku sva područja lijepoga, privući ga k umjetnosti, omogućiti mu da se po volji, vlastitom nagnuću i nadarenosti osposobi za estetsku komunikaciju s jednom ili više grana umjetnosti, učiniti ga osjetljivim za nematerijalne vrijednosti i maštovitijim, otvorenijim za nove izraze i oblike na području umjetnosti - to su temeljni razlozi za osnivanje, razvijanje i unapređivanje učeničke kinoamaterske aktivnosti." (Težak, 2002, 421)

Organizacija kino/video kluba zanimljiva je jer filmove mogu snimati već predškolska djeca. Istraživanja pokazuju da kinokamera može postati vrlo zanimljiva igračka u rukama djeteta koja ga vodi u svijet filma, ali i osposobljava za aktivno komuniciranje audiovizualnim sredstvima. Najčešće se organiziraju grupe prema određenoj dobi mada i mješovite grupe imaju svojih prednosti. Ako se rad dobro organizira mlađa djeca brže uče uz stariju i postupno preuzimaju sve složenije i teže zadatke. Škola animiranog filma u Čakovcu obuhvaća djecu od 7 do 18 godina i postiže velike uspjehe o čemu svjedoče i strani svjetski autoriteti. Gospodin Edo Lukman osnivač i voditelj ŠAF-a organizira rad u dvije osnovne grupe. Prvu grupu čine djeca početnici i kroz jednu godinu upoznaju se s osnovnom teorijom i karakteristikama animiranog filma, zatim svaki od njih realizira kratki crtani film - vježbu. Svi učenici koji završe film - vježbu prelaze sljedeće godine u grupu u kojoj rade s ostalima članovima kluba. Tu oni upoznaju razne vrste i mogućnosti animacije, te individualno ili u grupi realiziraju svoje prve filmove. Ovisno o interesima djeca se opredjeljuju za određene poslove pa u klubu djeluju mali scenaristi, animatori, crtači i snimatelji. Talentiraniji učenici samostalno rade svoje autorske filmove.

Osnivač i voditelj najuspješnijeg kinokluba Slavica u Pitomači - Mirko Lauš organizira rad na peterodijelnom programu:

1. osnove filmskog i TV stvaralaštva i filmskog jezika

2. pristup gledanju filmova i TV emisija

3. filmska i video tehnika

4. proces stvaranja filma ili videoprograma

5. prezentacija filmova i videoprograma.

Nema đačke aktivnosti s kojom kinoklub ne bi mogao surađivati ili naći razloge za suradnju. Mnoge su aktivnosti koje se izravno mogu ugraditi u rad na filmu (dramska, likovna i fotoamaterska sekcija, glazbene grupe, folklorne, plesne).

\section{Filmske radionice}

Filmske radionice nisu zamjena za kinoklubove i videoklubove niti njihov nadomjestak. Radionica je organizacijski oblik tečajnog karaktera koji omogućuje stvaralački susret s filmom učenika pa i odraslih kojima se nije pružila prilika za kontinuirani rad u dobro ustrojenom i vođenom klubu. Ona može biti začetak novog kinokluba. Filmske radionice mogu biti jednodnevne, trodnevne, višednevne, tjedne, već prema mogućnostima organizatora i voditelja radionice. Mogu se ponavljati u određenom vremenskom ritmu kako bi se početnicima omogućio stanovit razvoj, na primjer prvo radionica dokumentarnoga filma, drugo radionica igranoga, treće radionica 
animiranoga itd. U radionicama djeca stječu osnovna znanja o filmu i nastajanju filmskog djela i odmah prelaze na ostvarivanje vlastitog filma (ideja, scenarij, snimanje). Organizacija rada ovisi o trajanju, izboru radnog zadatka i nadahnuću voditelja. Zajednička im je težnja da se polazi od spontane inspiracije svakog sudionika, da se stvara vedro ozračje, da se postiže kvaliteta $\mathrm{i}$ jedinstvo stila unatoč većem broju sudionika. Filmska radionica shvaća se kao poticanje mašte, interesa za eksperiment i ovladavanja audiovizualnom komunikacijom.

Hrvatski filmski savez potiče i organizira raznovrsne filmske radionice u školama, kinoklubovima i drugim ustanovama koje se bave odgojem djece i mladeži.

\section{Usmjeravanje i vođenje dječjeg filmskog stvaralaštva}

Pri vođenju djeteta u filmsko stvaralaštvo važne su tri etape: promatranje okolice kroz objektiv kamere, maštanje kamerom i istraživanje komunikacijskih mogućnosti kamere.

Dijete treba navesti da promatra svijet oko sebe vlastitim očima a nakon toga kroz objektiv kinokamere. Gledajući kroz kameru dijete će otkrivati i odabirati pojedinosti skrivene u zakutcima. Otkrit će i nove vrijednosti u spajanju dviju sličica koje u prirodi ne stoje jedna do druge. Kad uznapreduje u „pisanju" kamerom shvatit će da se filmski tekst može kretati u dva suprotna pravca: u pravcu objektivističkog bilježenja fizičke stvarnosti i u pravcu subjektivističkog iskazivanja vanjskog svijeta. Dobro je da početnik vjerno zapiše vrevu mrava na mravinjaku, izlaženje i ulaženje pčela u košnicu, prve korake malog brata ili sestrice, kretanje automobila itd. „Tako postupno dijete ovladava novom komunikacijom i postaje umješan i uspješan pošiljatelj i primatelj filmske poruke. Dijete je otvoreno za nepoznato i pripravno je to nepoznato promatrati, raščlanjivati i povezivati u novu cjelinu, odnosno u novo životno iskustvo." (Težak, 2002, 430)

Dječja je mašta svježa i bujna, samo je valja razbuditi. U filmskom stvaralaštvu ona je nezaobilazan činitelj. Treba joj poticaj da se razigra. Nedovoljna, oskudna iskustva koče djecu da krenu u pustolovinu maštanja, no kad krenu mogu se očekivati originalna i zanimljiva ostvarenja. Voditeljev prvi zadatak trebao bi biti izazivanje želje za filmskom igrom i poticanje imaginacije da djeca krenu stvaralačkom stazom. Mnogo je načina, ali treba i sreće. Mašta se najlakše budi umjetnošću. Kad gledatelj izlazi iz zamračene dvorane često nosi sa sobom i svoj film koji najčešće ostaje fantazija i tu se razvija ljubav prema filmskom stvaralaštvu. Organizirajući gledanje filmova primjerenih dobi, voditelj će podgrijavati želju u djeteta: ja mogu tako nešto snimiti, ali mogu $i$ drugačije. I druge umjetnosti su poticajne, naročito književnost, koja i velike filmaše opskrbljuje pričama. Često se pitamo možemo li tu priču filmski uobličiti ili u likovnoj umjetnosti možemo li ovu skulpturu filmom oživjeti, preoblikovati ili u plesu može li se od ove plesne igre razviti filmska priča, filmska čarolija? Možemo snimati film prema predlošcima: ja želim... ja sanjam... ja se bojim... ja se radujem.... Stvaranje težnje da se ovjekovječi, zaustavi trenutak vremena koje bježi, trenutak ljepote koji se neće ponoviti, trenutak uzbuđenja bilo kojeg neponovljivog snažnog doživljaja. Voditelj pri tome treba brusiti dječja osjetila za prave ljepote i istinska uzbuđenja. Potaknuti ih da od uhvaćenih ljepota stvaraju nove. Primjerice, ako dijete snima pčele u letu i uhvati 
kapljicu rose na listu u kojoj je odbljesak sunca tada može banalnu sliku proljetnog jutra pretvoriti u umjetnički prikaz i malu dramatičnu igru, naravno za koju je važno znanje o kretanju kamere. Poticajno je okušavanje u složenim poslovima pri stvaranju filma (scenarij, režija, gluma, glazba, montaža) kao i u različitim filmskim rodovima i vrstama, sadržajima i tehnikama. Posebno je poticajan uspjeh i spoznaja vlastite nadarenosti u pojedinom području.

Dijete treba stavljati u položaj istraživača, neka i sam otkrije izražajnu vrijednost kojeg pokreta i položaja kamere, po koji trik ili funkcionalno iskorištavanje drugih medija. Neka iskuša kako se kamerom može šaliti, maštati, misliti, brbljati, poučavati, rugati se, asocirati... Neka traži svoj izraz i okušava svoje mogućnosti u neograničenim vrstama, jer može snimiti film-esej, film-zagonetku, film-meditaciju, film-dnevnik, filmkrik. Kad steknu opširnije filmsko znanje svoju istraživačku naviku iskoristit će za stvarno eksperimentiranje. Voditelj je ovdje pomagač u prikupljanju recentne literature i prikazivanju dobrih filmova.

\section{Vrednovanje dječjeg filmskog stvaralaštva}

U vrednovanju filmskih i drugih umjetničkih pokušaja učenika valja imati u vidu dva stajališta: umjetničko i pedagoško. Ti kriteriji vrednuju dječje umjetničko izražavanje po tome koliko razvije djetetove sposobnosti umjetničkog kodiranja i koliko razvojem sposobnosti za umjetničko kodiranje doprinese razvoju djetetove ličnosti. To pretapanje umjetničkog i pedagoškog aspekta čini se veoma jasno i opravdano, ali u praksi može postati potapanje i umjetničkog i odgojnog. Tada voditelj preuzima vrlo delikatnu ulogu ocjenjivača, kritičara, presuditelja koji može svojim ocjenama ne samo nepravedno prosuditi pojedinom vrijednom djelu, već i krivo usmjeriti stvaralačke napore čitavih naraštaja. $U$ tom pristupu procjeni dječjeg filmskog stvaralaštva moguće su dvije zablude: da ocjenjivač gleda samo iskusnim okom znalca ili da se muči gledanjem kroz oči samog stvaraoca, tj. očima dobi kojoj stvaralac pripada. Važno pitanje koje si postavljamo uz prvu zabludu jest misao: je li nam bitan krajnji rezultat ili je bitan čin stvaranja, nastanka pojedinog filma? Dijete nije jedinstvena kategorija, ne mogu biti ista mjerila za čin šestogodišnjaka ili dvanaestogodišnjaka, a da ne govorimo o mladenaštvu. Ne možemo jednakom mjerom mjeriti početniku i onom koji se već godinama bavi kinoamaterizmom.

U vezi s drugom zabludom nameće se pitanje: može li odrasli, iskusni filmski znalac gledati djelo očima djeteta? Ne bi bilo dobro dječji kut gledanja sasvim zanemariti pri vrednovanju dječjih stvaralačkih pokušaja. Kut gledanja mladog autora nije nevažan pri ocjeni vlastitog ostvarenja.

Prema autoru S. Težaku postoje tri bitna elementa analize i ocjene kinoamaterskog stvaralaštva:

1. sadržaj (nov, istinit, iskren, tj. autorovu biću primjeren, zanimljiv i s nekog stajališta važan)

2. izraz (usklađen sa sadržajem, izabranim oblikom i namjenom, sugestivan, osebujan, tehnički čitljiv i uredan) 
3. autorov/autorski stvaralački pomak (koliko je vidljiv napredak autora ili autorske ekipe u svem dotadašnjem radu).

Treba razlikovati dva tipa stvaralačkog djelovanja: vježbu i ostvaraj među kojima su granice katkad fluidne i teško odredive. Stoga procjenjivač kinoamaterskih uradaka mora razlikovati: dob autora, namjenu, i u vezi s tim izbor roda i vrste, vježbu i ostvaraj, djelo pojedinca i djelo kolektiva, ostvaraj potpuno samostalan i ostvaraj kojemu je kumovao odrasli savjetnik, proces stvaranja i rezultat stvaranja.

„Dječje filmsko stvaralaštvo doživljava vrhunac u razdoblju od 1975. do 1980. godine kad se na revijama javlja 34-44 kluba s 81-103 filma. Stanovita stagnacija, kvantitativna, započinje početkom osamdesetih godina i očituje se u smanjenju broja aktivnih klubova, pa onda i u broju ostvarenja devedesetih godina, traje sve do poratne 1996. godine... Vrednovanje, kao i u drugim područjima stvaralaštva mladih, ima prije svega motivacijsku ulogu. Pri tom bi valjalo zadržati ujednačenost kriterija (pristupa) u valorizaciji, jer promjene u pristupu valorizaciji mogu zbunjivati mlade autore, ali i voditelje. Naravno da se estetski kriterij ne može izostaviti, ali valja uvažavati i dob mladih, kao i inovativnost $\mathrm{i}$ originalnost $\mathrm{u}$ pristupu u prispjelim radovima... Bitno je, dakle, da stručni žiriji u svojim prosudbama bitno ne mijenjaju stavove u pristupu stvaralaštva mladih, a da uvažava promjene koje se događaju u tehničkoj sferi medija." (Kermek-Sredanović, 2002, 57)

\section{Voditelj u dječjoj radionici}

Voditelj medijske kulture ili filmske radionice mora biti znalac, prijatelj učeniku i filmu, ličnost i stvaralac. Za uspješnu nastavu nije dovoljno znati onoliko koliko učeniku treba dati, već i za uvođenje predškolskog djeteta u svijet filma odgajatelj mora imati filmsku naobrazbu koja prelazi okvire općeg obrazovanja. Događa nam se katkada da mladi nadmašuju učitelje u informiranosti o multimedijskim sadržajima i u računalnom obrazovanju. I to su bitni razlozi za permanentno obrazovanje voditelja ne bi li oni u klubovima/družinama doista bili suvremeni voditelji.

U današnjem tehnički razvijenom svijetu, uz sve dosad rečeno, stvaralaštvo mora postati sastavnim dijelom nastavnog programa budućnosti. Stoga je nužno pripremiti nastavnike na nastavničkim visokoškolskim ustanovama za stvaralački rad. „U današnjim oblicima nastave oni nisu imali mogućnosti upoznati se $s$ tehnikama snimanja, a kamoli s estetikom (u prvom redu fotografije i videa; filmsko stvaralaštvo je bilo samo pasivna komponenta u analizi filma). Škole su u općoj gospodarskoj krizi bile tehnički slabo opremljene, pa se razvijalo samo ono stvaralaštvo koje je bilo najjeftinije (a i najtradicionalnije), kao scensko, likovno, literarno i glazbeno." (Mikić, 2001, 238) Nastavnici bi morali, osim teoretski, i praktično ovladati potrebnom opremom za snimanje i projekciju filma. Tehnika i stvaralaštvo usko su povezani pa bi učitelji razredne nastave kao i nastavnici likovnog i hrvatskog jezika trebali imati kolegije iz tehničke kulture. „Svi oni bi u školi trebali postati vodiči filmskih i video grupa. Morali bi znati kako organizirati jednu grupu i motivirati je za samostalan stvaralački rad u tim medijima. Učitelji bi tijekom školovanja trebali dobiti osnovnu motivaciju, radno se osposobiti da vode učenike kroz produkciju filmskog ili video rada, a kasnije za aktivnu medijsku analizu, kako djela koja su nastala zajedničkim radom, tako i tuđih, već 
potvrđenih vrijednosti. Glavna inicijativa i motivacija mora poteći od nastavnika." (Mikić, 2001, 238)

Nagli razvoj medija traži drugačiju medijsku izobrazbu nastavnika. Oni bi trebali, osim medija filma, njegove teorije i povijesti, na sličan način upoznati i fotografiju i video kao srodne medije. Svim medijima trebalo bi ovladati praktički pa ih više primjenjivati u radu s djecom koja obožavaju medije i žive u suglasju s njima. U škole bi trebalo uvoditi medijske pedagoge koji bi osposobljavali i uvodili učenike u svijet audiovizualnih medija a time bi i naša škola zaista postajala suvremena škola koja se može nositi s medijskim izazovima.

\section{Organizacija filmske radionice u društvu naša djeca motovun: od ideje do premijere}

U Motovunu postoji DND koji pomaže razvoj i odgoj djece, zalaže se za ostvarivanje prava djece i organizira skupne aktivnosti djece i roditelja u slobodnom vremenu. Kako u Motovunu, malom gradiću, između ostalog poznatom i po velikom motovunskom filmskom festivalu, koji se nažalost, s danom prednosti engleskom jeziku, zove Motovun Film Festival, uvijek postoji netko zainteresiran za film, odlučili smo pokušat formirati dječju filmsku skupinu, kao radionicu, u kojoj bi djeca stvarala filmove na način koji smo mi nazvali od ideje do premijere.

Radionica ima namjeru aktivirati dječju osjetljivost za medije (posebno film) i razvijati medijsku kulturu koja je sve prisutnija u životu svakog djeteta. Smisao je provoditi dane u učenju, zabavi, druženju i radu kreirajući aktivnosti tako da svatko, i djeca i odrasli, svojim sposobnostima i mogućnostima doprinosi u procesu stvaranja filma. Konačni produkt - film - želimo prikazati javno u Kinu Bauer za sve zainteresirane građane i prijaviti na natjecanje u dječjem filmskom i videostvaralaštvu, koje se organizira na nivou Hrvatske, a promiče ga Hrvatski filmski savez.

Ciljevi radionice su sljedeći:

- razvijati kod djece kritičko i stvaralačko mišljenje u odnosu na medijsku kulturu

- šriti dječje doživljaje i spoznaje o filmskim izražajnim sredstvima i različitim filmskim rodovima i vrstama kroz samostalan stvaralački rad na filmu

- utjecati na kulturu življenja i aktivno provođenje slobodnog vremena

- senzibilizirati djecu za aktivno sudjelovanje u životu svoje zajednice, druženju sa prijateljima - vršnjacima, uvažavanju, toleranciji, slobodi izražavanja...

U radionicu djeca se uključuju po vlastitom izboru, a roditelji djece ne plaćaju ništa jer potrebne investicije ulaže DND Motovun. Ovim načinom društveno organiziranog slobodnog vremena izravno utječemo na prevenciju ovisnosti, jer sva djeca imaju mogućnost uključiti se s obzirom da ne trebaju financijski participirati. Uviđamo kroz godine rada da imamo uvijek u radionici i djecu iz socijalno ugroženih obitelji koja, slobodno se može reći, izvrsno napreduju i vrlo su redovita u radu. Još jedan važan segment našega rada vezan je uz dva voditelja od kojih je jedan muškog, a drugi ženskog spola, pri čemu u svakoj radnoj godini, tj. skupini, imamo djecu oba spola uglavnom u istom broju: smatramo da djeca vole tražiti uzore u voditeljima i da je 
važno u izvannastavnim ili izvanškolskim aktivnostima imati i muškarce i žene, jer su djeca kroz školovanje već pomalo prezasićena utjecajem ženskog spola.

Organizaciju radionice artikulirali smo na sljedeći način: uvodni susret, razgovor o izboru teme i ideja za film, upoznavanje osnova dječjeg stvaralaštva i filmskog jezika, izrada sinopsisa i scenarija, upoznavanje filmske tehnologije, snimanje, montaža, ozvučavanje filma, premijera filma - stvaralačkog uratka.

Radionica bazirana je na stvaralaštvu djece pa je njeno trajanje nedefinirano, ponekad se duže zadržavamo na izboru teme, a ponekad na snimanju i montaži. Okvirno vrijeme postoji, ali često ovisi o vrsti filma za koji se odlučimo. Radimo ili dokumentarni ili igrani film s djecom. Za oba roda važna je dobra priprema, a kasnije u igranom određujemo tempo glume dok u dokumentarnom ovisimo o vremenu koje nam odrede, npr. osobe koje smo planirali intervjuirati.

Da bi se djeca bavila stvaralaštvom neophodno je da steknu određenu filmsku kulturu. Stoga je dob djece u našoj radionici od petog do osmog razreda i povećava se srednjoškolskim uzrastom, djecom koja završe osmi razred a žele ostati u radionici. Uz glavni cilj, povećanje teorijskog i praktičnoga znanja i dobro organizirano slobodno vrijeme, važan je i rad na sebi kao sporedni cilj. Članovi grupe moraju zaslužiti uspjeh, uspješan glumac, režiser, snimatelj, mora raditi na sebi, jer mogućnosti koje se otvaraju samo su nova prilika za učenje. Dozvoljavamo improvizaciju, ona je čudesno sredstvo za samoizražavanje, promatranje i kreativnost. Ona je vrlo učinkovita metoda za otkrivanje i razvoj karaktera. Improvizacija je odskočna daska za stotinu ideja koje smo zapisivali i isprobavali da ih podijelimo s drugima. Improvizacija je poticajna, zabavna i obrazovna. Samostalnost, kreativnost, sloboda u izražavanju, razvoj dobrih prijateljskih odnosa, uvažavanja, tolerancije, zabave, aktivno sudjelovanje u životu zajednice u premijernom prikazivanju temeljni su dugoročni ciljevi motovunske radionice.

Djeca sama određuju koju ulogu žele u filmu (glumac, snimatelj, režiser, tonmajstor...) i dalje se prema afinitetu angažiraju. Razmišljanjima svi utječu na pojedinu ulogu ili sadržaj pa se često brani svoj stav ili čini kompromis. Ovdje se vidi koliko je tanka nit između voditelja i članova, gotovo su svi izjednačeni u procesu stvaranja. Ponekad se dogodi zanimljiva situacija kao ona u filmu Nera u kojoj se mijenjala knjiga snimanja jer se djevojčica u ulozi mame strašno boji psa. Dječja domišljatost ima smisla pa se tako često snime zanimljivi kadrovi koji vesele i često pomognu logičnijoj motiviranosti priče, a koji put teško ih je izbaciti iako film mora biti jasan, jezgrovit i kratak.

Radionicu ravnopravno vode dva voditelja: Sandra i Boris. Sandra je učiteljica, a Boris snimatelj. Sandra se više bavi idejom, stvaranjem sinopsisa, scenarija i knjigom snimanja, a Boris samim snimanjem, ozvučenjem i montažom filma. Pretpostavljamo da ravnopravnost kod voditelja utječe i na ravnopravnost kod djece pa je u radionici jednak broj dječaka i djevojčica u skupini. U interakciji odgojno-obrazovne i snimateljske struke djeca dobivaju višu kvalitetu i stručnost. Voditelji pozitivnim primjerima potiču usredotočenost u radu, dosljednost u postavljanju i poštivanju pravila i podržavaju uspjeh u radu. Pohvala publike djeci je značajna i utječe na smanjenje rizičnih čimbenika povećava kompetencije u pozitivnim modelima ponašanja. Unutar radionice djeca različito napreduju. Dvoje se djece uzdiglo u znanju i sposobnosti pa mogu kroz daljnje školovanje razvijati znanja i vještine i u profesionalnom smislu. 
Kako sredina podržava rad ove radionice užitak je organizirati rad u prostorijama DND, škole ili na vanjskim prostorima i tražiti ono što je potrebno da bi se ideja realizirala. Na kraju moramo zaključiti: važniji je proces stvaranja od samog filmskoga djela.

DND Motovun proširio je rad Dječjim filmskim kampom, a možda će u skoroj budućnosti imati i dječji filmski festival. U zajedničkoj organizaciji DND Motovun i Hrvatskog filmskog saveza u Motovunu su održana dva dječja filmska kampa u ljetnim mjesecima. U Kampu sudjeluju djeca iz cijele Hrvatske zajedno sa svojim voditeljima. Ideja je Kampa druženje, razmjena ideja i znanja o filmskome stvaralaštvu i izrada kratkoga filma. U Kampu djeluju dvije radionice: radionica za dokumentarni film i radionica za igrani film. Polaznici se samostalno opredjeljuju, vrlo su angažirani i aktivni u radu što se vidi na projekciji zadnjega dana Kampa. Slabe su točke kratko trajanje i brzi tempo rada.

\section{Uvodni susret - motivacijski, dogovorni, slobodan izbor}

Povodom Dječjeg tjedna u kino sali Bauer organizirane su projekcije filmova iz područja dječjeg filmskog stvaralaštva za djecu osnovne škole u mjestu.

Prikazana su četiri filma u vremenskom trajanju jednog školskog sata:

1. NEMA TAJNE (reportaža koju su radila djeca Motovuna)

2. KAPIŠ (dokumentaran film o doseljenicima u malom mjestu Tinjan) dječaku)

3. ONA I JA (igrani film, prema tekstu iz čitanke za šesti razred o zaljubljenom

4. INTERNET IZ NAŠEG RAKURSA (ostale vrste, djeca istražuju znanja i korištenja internetom).

Nakon prikazivanja voditelji su djeci dali anketni listić koji će popuniti u školi i vratiti kako bi se znalo koji im se film najviše svidio.

Putem oglasne ploče djeca su obaviještena da počinjemo filmska radionica koja će se održavati svaki petak od 17 sati u prostorijama DND-a. Na ovaj poziv odazvala su se djeca isključivo po vlastitom izboru i želji. Stvorena je grupa od dvanaest djece.

\section{Razgovor o izboru teme i ideje za film}

Igrom „oluja mozgova" nabrajaju, nabacuju i izmišljaju ideje koje bi mogle postati filmične. Raspravlja se o njihovoj ostvarljivosti, privlačnosti, prilagođenosti tehničkim mogućnostima... Nakon toga eliminacijom se smanjuje brojnost ideja, odnosno, ako postoje slične, udružuju kako bi nastala kompaktnija cjelina.

Izboru teme posvećuje se nekoliko susreta, jer se želi da ona ostane dječja a ne voditeljeva. U prevelikoj revnosti oko odgojne strane filma voditelji katkad i nehotice „sufliraju" malim filmašima ideje, efektne prizore, gegove, poante... Djeca ponekad to prihvaćaju zato da ugode svojim pretpostavljenima, ali to im se ne sviđa. Tada se prati „dobra odgojenost", ali ne i iskrenost, prirodnost i druge osobine djetinjstva koje su posebno važne i trebaju doći do izražaja u dječjem stvaralaštvu. 
Pri razgovoru o idejama raspravlja se i kojem rodu će pripadati naš film pa tako djeca najlakše ponove filmske rodove i vrste.

Uz gledanje izabranih filmova dječjeg stvaralaštva, ali i filmova koji su rađeni za djecu a nagrađeni su na međunarodnim dječjim festivalima, razgovora se o djelu kao cjelini, o izražajnim sredstvima, o likovima... U tu svrhu izrađen je poučan materijal Mala filmska škola koji ima svaki polaznik kao podsjetnik i aktivno ga može koristiti u radu.

Jedan je od rezultata „oluje mozgova" sinopsis kratkoga igranog filma NERA:

Dječak Filip, učenik osmoga razreda, s prijateljem ide u školu. Prijatelj ga podsjeća da toga dana pišu test iz matematike, ali Filip kao da ga opet nije čuo. Na povratku kući ugleda mamu kako mete stubište i prisjeti se da ga je zadnji put udarila metlom jer je dobio jedinicu. U strahu da opet ne proživi svađu s udaranjem odluči pobjeći od kuće.

Putem u šumi nalazi jabuke i kreće u nepoznato.

Mama se zabrinula zašto iz škole nije došao kući pa ga zove, traži njegova prijatelja i susjedu da joj pomognu naći sina. Kako nema uspjeha odluči zvati policiju.

Filip ne odgovara na mamine pozive, prestraši se nekoga zvuka, bježi kroz šumu $i$ u bijegu pada и јати.

Mama vidi da se njihova kuja Nera otrgnula s lanca, instinktivno trči za psom, osjećajući da Nera traži dječaka. I zaista, Nera stigne do školske torbe, mama trči za njom, a Filip viče iz jame. Mama pomaže Filipu pri izlasku iz jame.

\section{Upoznavanje filmske tehnologije, snimanje i montaža}

Članovi se vježbaju u baratanju kamerom, upoznaju njezina svojstva i mogućnosti (oštrina slike, zumiranje, kadriranje...) Radimo probna snimanja, gledamo snimljeni materijal i diskutiramo.

Kako bi djeca mogla raditi s kamerom, osim njenih mogućnosti važno je iz teorije naučiti o položajima kamere i važnosti tih položaja za filmsko djelo.

Formira se ekipa, utvrđuju zadaci za svakog pojedinca (organizator, redatelj, snimatelj, ton-majstor... Vježba se s glumcima, traže se i proučavaju tereni eksterijera i interijera na kojima će se snimati film.

U montaži sudjeluju svi. Ideje i prijedloge prihvaćaju ili odbijaju režiser i voditelj, a voditelj će uvijek objasniti kako montažni postupci utječu na ritam filma, ,preskoke u priči", vrijeme i prostor priče. Važan je rad i djeteta koje tehnički montira film.

Kako je kadar ,abeceda" filma navodimo nekoliko kadriranja filmskih planova u već spomenutom filmu NERA:

1. kadar: total (opći plan) - vidi se cijeli razred i učiteljica

2. kadar: srednji plan - vidi se učenik koji piše test

3. kadar: srednji plan-učenik predaje test profesoru

4. opći plan-učenici uzimaju torbe i izlaze iz razreda

5. detalj-vide se Filipove oči i lice 
Radi uštede prostora ne donosimo crteže koji prate svaki od ovih kadrova.

\section{Ozvučenje filma (glazba)}

Djeca sama biraju glazbu za film, ako postoji netko tko ide u glazbenu školu može i sam stvarati glazbu. Moramo priznati da je u dosadašnjem radu najteže bilo izabrati glazbu, ali ako u skupini postoji dijete koje je glazbeno senzibilizirano onda je sve u redu. Ukoliko takav ili takva ne postoje, onda smišljamo druge načine ozvučavanja filma.

Glazba je nadahnuće i poznata glazba iz poznatih filmova često inspirira ili podsjeti na neke važne trenutke, zato o glazbi treba još više učiti i treba ju više slušati i birati kako bi se razvila osjetljivost za glazbene isječke.

\section{Premijera (projekcija) filma}

Ovo je za sve sudionike radionice najveseliji, najuzbudljiviji, najsretniji dio rada. Ujedno je to provjera rezultata, analiza, ocjena, vrednovanje sveukupnog rada skupine. Posebno veseli kad se odazove veći broj ljudi, tj. kada se napuni mjesno kino. Tada djeca i voditelji shvate da nisu sami i da se mnogi interesiraju za njihov rad. Nakon premijere djeci se pokloni primjerak nastalog filma i zahvalnicu. Još bi valjalo proučiti kako organizirati uvodnu riječ i razgovor nakon filma s publikom a da on bude zanimljiv i konstruktivan.

\section{Zaključak}

Film djeca jako vole i stoga ga možemo koristiti na bezbroj zanimljivih načina u odgojno-obrazovnom radu. Postoje filmovi koji su propisani programom i gledaju se u osnovnoj školi, o njima se razgovara, radi se analiza i sinteza, iznose doživljaji i na taj način interpretacija se ne razlikuje bitno od književnog djela. Vrlo je malo škola u kojima djeca imaju prilike samostalno stvarati filmove i kroz vlastito iskustvo spoznavati koji utjecaj medij ima na društvenoj i na osobnoj razini. Izvannastavne i izvanškolske aktivnost mogu popuniti ovu prazninu i okupljati djecu prema interesnim područjima i učiti ih da je važno aktivno provoditi slobodno vrijeme.

Djeca kroz rad u filmskoj radionici stječu osnovna znanja o filmu i nastajanju filmskog djela te odmah prelaze na ostvarivanje vlastitog filma (ideja, scenarij, snimanje, montaža, prikazivanje). U radionici je važna inspirativna atmosfera, vedro ozračje i tada se razbuktava mašta, interes za novo djelo te ovladava audiovizualnom komunikacijom. Bez obzira hoće li dijete aktivno koristiti stečene spoznaje kasnije u životu ili će biti sudionik radionice radi dobrog druženja i zabave, uvijek će neki njemu važan doživljaj ostati, a voditeljima je važno da je dijete spoznalo kako aktivno koristiti slobodno vrijeme i kako formirati vlastiti kritički stav prema filmu i drugim medijskim sadržajima. Dječja filmska radionica najkreativnija je metoda bavljenja filmskim medijem. Znanje o filmu podrazumijeva se kao zamišljena situacija u kojoj pravila i kreativnost ne moraju rezultirati filmskim djelom. Radionica mora postati osnovnim 
oblikom dječjega bavljenja filmom i pretpostavka je kinoklubu od kojeg se ipak očekuje rezultat na kompetitivnim smotrama i festivalima.

Smatramo da kino-video tehnika danas nije skupa i da nije prepreka bavljenju filmskom radionicom u školi ili u užoj društvenoj sredini. Veći je problem od materijalnog položaja nastavnika njegov društveni ugled i status. Rijetke su sredine kao Motovun koje podrazumijevaju da je kinodvorana prirodan prostor za projekcije filmova Društva Naša djeca. Pokojnoga Branka Bauera sigurno bi oduševila ideja o projekcijama filmova iz dječje radionice u „njegovoj"dvorani.

\section{Literatura}

Aristarco, G. (1974): Historija filmskih teorija, Univerzitet umetnosti, Beograd

Čudina-Obradović, M. (1991): Nadarenost, razumijevanje, prepoznavanje, razvijanje, Školska knjiga, Zagreb

Glasser, W. (1994): Kvalitetna škola, Educa 11, Zagreb

Kermek-Sredanivić, M. (2002): Kreativnost mladih i nove tehnologije, Zapis-poseban broj, Hrvatski filmski savez, Trakošćan

Košir, M, Zgrabljić, N, Ranfl, R. (1999): Život s medijima, Doron, Zagreb

Krelja, P. (2009): Kao na filmu - Ogledi 1965-2008, Hrvatski filmski savez, Zagreb

Mikić, K. (2001): Film u nastavi medijske kulture, Educa, Zagreb

Parkinson, D. (1995): Film, SysPrint d.o.o, Zagreb

Peterlić, A. (2000): Osnove teorije filma, Hrvatska sveučilišna naklada, Zagreb

Peterlić, A. (1976): Pojam i struktura filmskog vremena, Školska knjiga, Zagreb

Peterlić, A. (2002): Studije o devet filmova, Hrvatski filmski savez, Zagreb

Petrić, V. (1971): Osma sila, RTV Beograd, Beograd

Plemenčić, Đ. (1982): Obrazovna djelotvornost televizije, Školska knjiga, Zagreb

Pletenac, V. (1986): Odgojna i obrazovna funkcija televizije, Školske novine, Zagreb

Scher, A. i Verral, C. (2005): 100+ideja za dramu, Hrvatski centar za dramski odgoj-PiliPoslovi d.o.o, Zagreb

Tadić, Z. (2009): Ogledi o hrvatskom dokumentarcu, Hrvatski filmski savez, Zagreb

Težak, D. (1990): Dječji junak u romanu i filmu, Školske novine, Zagreb

Težak, S. (1979): Literarne, novinarske, recitatorske i srodne družine, III. Izdanje, Školska knjiga, Zagreb

Težak, S. (2002): Metodika nastave filma na općeobrazovnoj razini, Školska knjiga, Zagreb

Turković, H. (1988): Razumijevanje filma, Grafički zavod Hrvatske, Zagreb

Turković, H. (1999): Suvremeni film, Znanje d.d, Zagreb

Turković, H. (2000): Teorija filma, Meandar, Zagreb

Turković, H. (1996): Umijeće filma, Hrvatski filmski savez, Zagreb

Vrabec, M. (1967): Film i odgoj, Školska knjiga, Zagreb

Zapis, 2001 - 2008, Glasilo Hrvatskog filmskog saveza

Zrno, 88-89/2009 -2010, Časopis za obitelj, vrtić i školu 
Metodički obzori 6(2011)2

Professional article

UDK: 371.686:061.237-053.2(497.5 Motovun)

Received: 11. 6. 2010.

\title{
FILM IN THE CHILDREN'S WORKSHOP on the example of the association Društvo Naša djeca, Motovun
}

\author{
Sandra Vlahov, diplomantica \\ Department of educational sciences, \\ Juraj Dobrila University of Pula (Croatia) \\ e-mail: sandra.vlahov2@pu.t-com.hr \\ Mr. sc. Ivan Grgurević \\ Department of educational sciences, \\ Juraj Dobrila University of Pula (Croatia) \\ e-mail: grgurevic.ivan@gmail.com
}

\section{S u m m ary}

The paper is based on the fact that modern society is flooded with media (press, photography, film, television, video, Internet, computer games). Children grow up together with them without the large influence of their parents, teachers or other adults. The media widen the knowledge and experience of children and should not be fought against with ban, censure or censorship but by learning about the media and their character. The final aim is to "understand the media" and creatively use their features.

The topic of our paper is the film medium in a children's workshop. We endeavoured to indicate the influence of film (screen) on education, the need to introduce film classes in school, and we described a possible form of extracurricular activity for children. On the example of the Film Workshop organised by the association Društvo Naša djeca Motovun we attempted to display all actions and procedures "from the idea to the premiere" (first meeting, discussion to choose the topic and idea of the film, production of the synopsis and scenario, introduction to film technology, shooting, editing, sound, premiere).

We concluded that the most efficient method is for children to learn and understand "characteristics and effects" of the media (McLuhan) as part of a knowledge and creativity game when shooting a film during a children's workshop. As an essay is a stage following after reading and writing have been learned, film and video film are more than just basic knowledge on the means of expression and children quickly sense that film is a specific medium where personal creativity, amongst other things, must be matched with different creativities. Film workshops should provide the fundamental form of children's involvement in film and is the precondition to cinema clubs. If the film product fails, some of the audiovisual communication skills will remain, together with a critical attitude towards the medium or creativity in playing. Unlike in cinema clubs, this is quite sufficient for a film workshop.

Key words: medium, film, children's workshop, Motovun 